\title{
АНАЛІЗ ЕФЕКТИВНОСТІ ВИКОНАННЯ ЦЕНТРАЛІЗОВАНИХ ДЕРЖАВНИХ ПРОГРАМ ЗІ ЗАБЕЗПЕЧЕННЯ ХВОРИХ НА ЦУКРОВИЙ ДІАБЕТ ПРЕПАРАТАМИ В УКРАЇНI
}

\author{
${ }^{1}$ Д. фарм. н, професор, Панфілова Г. Л., ${ }^{2} \kappa$. фарм. н., асистент Цурікова О. В., \\ ${ }^{2}$ к. фарм. н., дочент Ткаченко О. В, ${ }^{2}$ к. фарм. н., доцент Ромелашвілі О. С., \\ ${ }^{1} \kappa$. фарм. н., доиент Чернуха В. М. \\ ${ }^{1}$ Украйна, м. Харків, Національний фармацевтичний університет, кафедра організаиї та \\ економіки фармачії \\ ${ }^{2}$ Украӥна, м. Харків, Наџіональний фармацевтичний університет, кафедра управління, \\ економіки та забезпечення якості у фармачії
}

\section{DOI: https://doi.org/10.31435/rsglobal_conf/30112020/7274}

Abstract. B статті представлені результати аналізу рівня виконання держаних иільових програм зі забезпечення хворих на иукровий діабет необхідними ліками, а також оновленої редакиії Реєстру лікарських засобів, що підлягають реімбурсаиії у відповідності до наказу МОЗ України від 11.08.2020 р. № 1851. Встановлено, що у 1998 р. була запроваджена в Україні перша цілььова програм «Цукровий діабет» на 1998-2001 рр.. У подальшому, було розроблено та прийнято ще дві програми на 2002-2007 рр. та на 2009-2013 рр. Доведено, що рівень їх виконання за фінансовими показниками коливався у діапазоні значень від 81,6\% (1999 p.) до 104,1\% за даними 1998 р., а з 2004 р. (з 94,3\% до 98,1\%) до 2013 р. спостерігався відносно стабільний характер змін зазначеного показника.

нання зазначених иілььових програм. За результатами аналізу Реєстру лікарських засобів за асортиментом ліків, щзо відпускаються хворим на иукровий діабет за програмою "Доступні ліки» встановлено, що зазначений перелік містить 48 асортиментних позицій, серед яких 79,17\% припадає на препарати А10ВА02-Метформіну, 14,58\% на препарати А10ВВ09Гліклазиду, а всього 6,25\% на ліки із групи А10ВВ01-Глібенкламіду. Встановлено, що домінуючи позиії у зазначеному асортименті займають імпортні ліки (Глібенкламід -100,0\%, Гліклазид 57,14\%,Метформін - 78,95\%).Найбільш доступними є препарати Глібенкламіду. Лише дві асортиментні позийї препаратів можуть бути відпущені без доплати з боку паџієнта

Keywords: иукровий діабет, иентралізовані державні програми, иукрознижуючи препарати, фармачевтичне забезпечення.

Вступ. Цукровий діабет (ЦД) постає як тяжка патологія, що відноситься до значущих медико-соціальних проблем. Забезпечення хворих на ЦД ліками визнана у багатьох країнах як питання державного рівня виконання, а також воно $є$ пріоритетом для різних національних систем охорони здоров'я $[1,2,3]$. Так, за даними Міжнародної діабетичної федерації (International Diabetes Federation - IDF) нині в світі налічується близько 250 млн хворих на ЦД, a y 2030 p. їх буде близько 320 млн, а за іншими даними -понад 530 млн [4, 5]. Якщо ж враховувати пацієнтів із порушеною толерантністю до глюкози, то зараз таких хворих у всьому світі налічується 480 млн, тобто кожен 8-10-й чоловік має порушену інкреторну функцію підшлункової залози [6-8]. Керуючих твердженням, що ЦД є поліморфною патологією, можна відповідальне стверджувати, що лікування цих хворих є високозатратним процесом у будь-якої із національних систем охорони здоров'я.

У 2007 р. Організація Об’єднаних Націй звернулася до усіх глав держав із закликом створювати державні програми та вирішувати цілу низку проблем, пов'язаних із поширенням ЦД. За даними Всесвітньої організації охорони здоров'я (ВООЗ), ЦД є одним із найбільш поширених серед неінфекційних захворювань, кількість хворих зростає у геометричній прогресії, а сама патологія характеризується високим ризиком виникнення ускладнень, таких як діабетична ретинопатія, нефропатія, діабетична стопа $[4,6,8]$. Крім того, кількість випадків інфаркту міокарда та інсульту у хворих на ЦД значно вища, ніж у середньому в популяції [9-11]. Все це призводить до інвалідізації та передчасної смертності таких хворих. У більшості країн світу 
витрати, що пов'язані зі забезпечення хворих на ЦД ефективними препаратами та інсуліном бере на себе держава. Не виключенням із цього переліку країн є й Україна. 3 метою вирішення проблемі забезпечення хворих на ЦД II типу в Україні з 01.04 .2017 р. запрацювала урядова програма «Доступні ліки» $[17,18]$. При цьому слід зазначити, що реалізація цієї програми була високо оцінені міжнародною спільнотою, а саме ВООЗ [19-20]. Це була не перша спроба держави вирішити питання підвищення рівня доступності препаратів, які використовуються хворими на ЦД. Враховуючи вже існуючий досвід реалізації комплексу заходів, які спрямовані на підвищення рівня ефективності фармацевтичного забезпечення хворих на ЦД актуальним $\epsilon$ проведення аналізу рівня виконання фінансових зобов'язань, які бере на держава у напрямку забезпечення хворих на ЦД доступними та ефективними препаратами.

Мета дослідження - аналіз ефективності виконання централізованих державних заходів із забезпечення хворих на цукровий діабет необхідними препаратами у ретроспективі років.

Матеріали та методи дослідження. Для досягнення окресленої мети нами були розроблені наступні завдання досліджень: проаналізувати епідеміологічну ситуацію з ЦД у світі та в Україні; здійснити аналіз комплекс заходів, що спрямовані на забезпечення хворих на ЦД необхідними препаратами у ретроспективі років в Україні; оцінити рівень виконання зазначених програм за обсягами фінансування по рокам дослідження; окреслити основні характеристики процесу фінансового забезпечення у виконанні державних програм зі забезпечення хворих на ЦД необхідними препаратами; визначити проблеми у реалізації державних гарантій 3 надання хворим на цукровий діабет ефективної фармацевтичної допомоги.

Об'єктом досліджень став процес надання хворим на ЦД ефективної медичної допомоги та фармацевтичного їх забезпечення у рамках виконання відповідних державних гарантій за централізованими цільовими програмами.

Предметам досліджень були обрані: показники поширеності та захворюваності населення від ЦД в світі та в Україні; дані вітчизняної законодавчої та нормативно-правової бази, що регулює питання організації надання хворим на ЦД ефективної медичної та фармацевтичної допомоги, паспорти державних цільових програм по ЦД (програми за 1998-2001рp., 20022007 pp., 2009-2013 pр.) за обсягами фінансування та рівням виконання державних гарантів зі забезпечення хворих на ЦД препаратами інсуліну та цукрознижуючими ЛП. Крім цього, у дослідженнях використовувалися дані аналітичної системи дослідження фармацевтичного ринку (ФР) «PharmXplorer»/«Фармстандарт» (компанія «Proxima Research») [17,18].

Всі необхідні показники оброблялись за допомогою стандартного пакету статистичного аналізу Statistica (version 12.0, StatSoft, Tulsa, USA). В статистичних розрахунках значення $\mathrm{p}$ $<0,05$ вважалось статистично значущим.

У дослідженнях використовувалися системний підхід, а також історичний, логічний, порівняльний, графічний та математико-статистичні методи прикладних досліджень.

Результати та обговорення. За даними ВООЗ, в економічно розвинутих країнах світу до 4,0\%-6,0\% населення хворіє на ЦД [12-14]. В Європі питома вага (\%) таких хворих становить близько $4,0 \%$ [5, 12]. Визначаючи загрозу, яку становить для людства ЦД, Генеральна Асамблея ООН прийняла 20 грудня 2006 р. «Резолюцію про цукровий діабет», відповідно до якої витрати, пов'язані з наданням медичної допомоги хворим, оцінюються більш, як у 2,0\%-3,0\% від загальних видатків з охорони здоров'я. Майже 80,0\% припадає на лікування ускладнень, а $20,0 \%$ - на закупівлю цукрознижувальних препаратів і засобів контролю за рівням цукро в крові пацієнта $[6,9,15,16]$. В Україні зареєстровано близько 1 млн 300 тисяч хворих на ЦД і щорічно реєструють більше 100 тисяч нових випадків. Фахівці відмічають, що з кожним зареєстрованим існує 2-2,5 недіагностованих хворих [6,7].

Україна займається вирішенням проблем організації ефективної медичної та фармацевтичної допомоги хворим на ЦД ще з 1999 p. Так, у зазначеному році указом Президента України була започаткована перша програма заходів по боротьбі із ЦД в Україні. Одним із ключових питань, яке було у цій програмі, це організація безкоштовного забезпечення хворих високоякісними інсулінами вітчизняного виробництва. На даний час в України зазначене питання вирішено, працюють два заводи - «Індар» і «Фармак», а держава щороку виділяє близько 500 млн грн. на закупівлю інсулінів.

Для хворих ЦД з квітня 2017 р. запрацювала урядова програма «Доступні ліки», яка передбачає реімбурсацію вартості споживання цукрознижуючих препаратів Метформін (Metformin), Гліклазид (Gliclazide), Глібенкламід (Glibenclamidum) [17, 18]. Держава компенсує вартість найдешевшого лікарського засобу (Л3), який подав заявку на участь у зазначеній 
програмі. Такий препарат пацієнт матиме змогу отримати в аптеках безоплатно. Дорожчий препарат, ціна на який не перевищує граничну референтну, хворих на ЦД може отримати, доплативши різницю між мінімальною ціною та роздрібною ціною обраного найменування препарату. Ліки, ціна на які перевищує референтну ціну в 5 сусідніх країнах, не підпадають під програму відшкодування [17-20]. Також наявність препарату у програмі залежить від рішення про його участь від виробника - він має подати заявку для включення свого препарату до Реєстру ЛЗ, що підлягають реімбурсації.

Аналізуючи зміст усіх зазначених державних програм по боротьбі із ЦД в Україні можна стверджувати, що всі вони були розроблені та впроваджувалися 3 метою створення дієвої системи доступної медичної та фармацевтичної допомоги пацієнтам з ЦД та його укладеннями.

Використовуючи дані, які представлені на офіційних сайтах MO3 України нами було проаналізовано стан виконання державних гарантій з організації забезпечення хворих на цукровий діабет ЛЗ. Так, нами були досліджені дані паспортів комплексних програм «Цукровий діабет» за 1998-2001 pр. (Указ Президента від 21.05 .99 р. № 545/99), державної цільової програми «Цукровий діабет» на 2002-2007 pр. та 2009-2013 рр. (постанова КМУ від 19.08.2009 р. №877). Результати аналізу рівня (\%) виконання фінансових зобов'язань за означеними державними цільовими програмами у ретроспективі років наведені на рис. 1 та 2.

Фінансування державних гарантій за програмою «Цукровий діабет» здійснюється у переважній більшості за рахунок місцевих бюджетів адміністративно-територіальної одиниць країни $[19,20]$. Особливо це стосується фінансування фармацевтичної складової у вигляді організації та проведення тендерів на закупівлю інсулінів на рівні адміністративнотериторіальних одиниць країни.

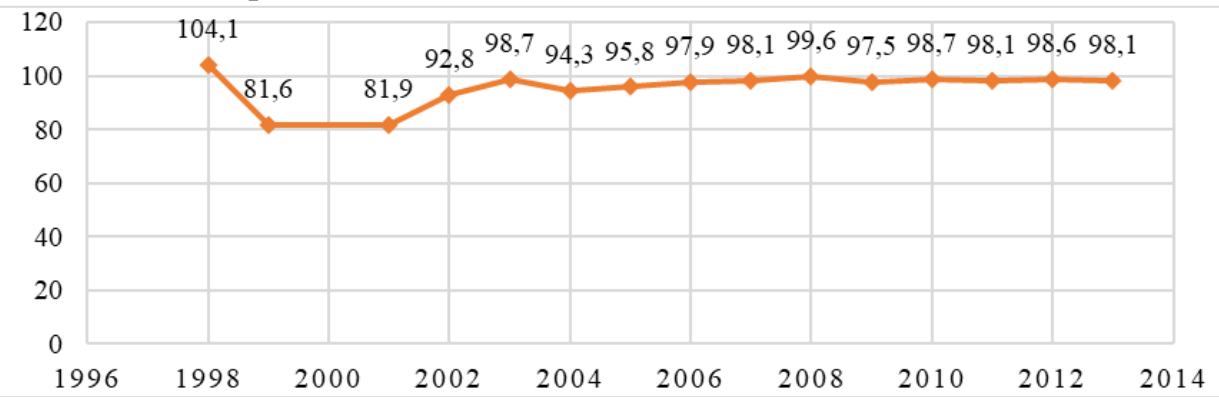

Рис.1. Аналіз рівня виконання державних гарантій зі забезпечення хворих на ЦД інсуліном та иукрознижуючими препаратами за цільовими програмами (центральний та місцевий бюджет) упродовж 1998-2013 рр.

Як бачимо за даними рисунків рівень (\%) виконання програм, які досліджуються коливався у діапазоні значень від 81,6\% (1999 р.) до 104, 1\% за даними 1998 р.. Звертає на себе увагу наявність більш стабільного характеру зміни показників рівня (\%) виконання державних гарантій з 2004 р. (3 $94,3 \%$ до 98,1\%) до 2013 р. Таким чином, можна констатувати, що упродовж 1998-2013 рр. держава на досить високому фінансовому рівні виконували взяті на себе зобов'язання стосовно забезпечення хворих на ЦД як інсулінами, так й препаратами цукрознижуючої дії.

Важливим напрямком вирішення питань підвищення рівня ефективності медичного та фармацевтичного забезпечення зазначеної групи хворих стало впровадження урядової програми «Доступні ліки». Так, спочатку до складу Реєстру ЛЗ, які підлягають реімбурсації за рахунок держаних коштів було віднесено два препарату за міжнародними непатентованими назвами (MHН). Це A10BA02-Метформін (Metformin), та A10BВ09-Гліклазид (Gliclazide). У подальшому був також включений А10BВ01-Глібенкламід (Glibenclamide). Як свідчать дані системи дослідження вітчизняного фармацевтичного ринку (ФР) «PharmXplorer»/«Фармстандарт» компанії «Рroxima Research» споживання торгових найменувань (ТН) препаратів цих 3-х ліків за МНН в останні роки збільшилось $[17,18]$. Зазначений факт $є$ важливою позитивною характеристикою процесу підвищення рівня економічної доступності ЛЗ для хронічних хворих, насамперед тих, хто страждає від ЦД ІІ типу.

12.08 .2020 p. на офіційному сайті МОЗ був оприлюднений наказ від 11.08 .2020 p. № 1851 [21]. У відповідності до цього наказу була затверджена нова редакція Реєстр ЛЗ, які підлягають реімбурсації, станом на 07.08.2020 р. (у подальшому Реєстр ЛЗ). Нормою, яка була прописана у зазначеному документі було встановлено факт втрати чинності наказу МO3 від 01.06.2020 p. № 1284, яким затверджувався попередній Реєстр ЛЗ. За результатами аналізу 
оновленої редакції Реєстру ЛЗ за асортиментом ліків, що відпускаються хворим на ЦД за програмою «Доступні ліки» встановлено, що зазначений перелік містить 48 асортиментних позицій, серед яких 79,17\% припадає на препарати A10BA02-Метформіну, $14,58 \%$ на препарати А10ВВ09-Гліклазиду, а всього 6,25\% на ліки із групи А10ВВ01-Глібенкламіду.

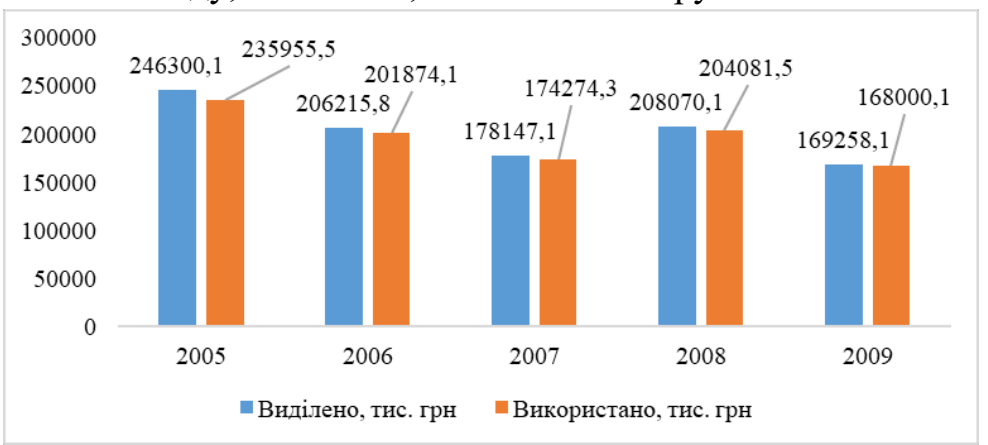

Рис.2. Аналіз динаміки фінансування та використання коштів иеетрального та місиевих бюджетів за відповідними заходами за програмою «Цукровий діабет» у 2005-2009 рр.

Встановлено, що співвідношення (\%) між вітчизняними та імпортними ліками у сукупності препаратів А10ВВ01-Глібенкламіду дорівнює 100,0\%:0\% (компанії ПрАТ «Технолог», ТОВ «Фармацевтична компанія «Здоров’я АТ «Фармак»), по групі А10ВВ09 Гліклазиду 57,14\%:42,86\%, а по препаратах A10BA02 Метформіну - 78,95\%:21,05\%. За даними аналізу рівня доплати за переліком ліків, що досліджується встановлено, що найбільш доступними, з економічної точки зору для вітчизняних хворих на ЦД II типу є препарати А10ВВ01Глібенкламіду, на другій позиції представлені препарати А10ВВ09 Гліклазиду, а на третій А10ВА02 Метформіну. Співвідношення (\%) між кількістю ТН які можуть бути відпущені без доплати та 3 доплатою з боку хворого дорівнює 100,0\%:0,0\%, 57,14\%:42,86\%, 78,95\%:21,05\% відповідно.

Доведено, що із асортименту імпортних ліків лише 2 асортименті позиції препаратів можуть бути відпущені без доплати з боку пацієнта. Це Метформін САНДОЗ® 500 мг (оптовавідпускна ціна 48,26 грн, а роздрібна - 65,32 грн) та 850 мг (оптова-відпускна ціна 82,04 грн, а роздрібна - 111,04 грн) №120 компанії Лек С. А. (Республіка Польща).

Підсумовуючи результати проведених досліджень можна стверджувати, що за умов підвищення показників захворюваності та поширеності ЦД серед населення країни та враховуючи обмежений характер ресурсного забезпечення національної системи охорони здоров'я важливим напрямком підвищення ефективності медичного та фармацевтичного забезпечення зазначених груп хворих повинно стати впровадження раціональних моделей використання коштів державного та місцевого бюджету.

\section{Висновки.}

1. Доведено, що реалізація централізованих та цільових програм забезпечення хворих на ЦД необхідними ліками значена програмам $\epsilon$ важливою складової процесу реформування всієї національної системи охорони здоров’я в Україні. У 2019 р. ВООЗ високо оцінила ефективність реалізації урядової програми «Доступні ліки», особливо у напрямку підвищення рівня економічної доступності ЛЗ для хворих на серцево-судинні патології та ЦД ІІ типу.

2. За даними ретроспективного аналізу встановлено, що Україна розпочала боротьбу з ЦД ще с моменту проголошення своєї незалежності, а у 1998 р. була запроваджена перша цільова програм «Цукровий діабет» на 1998-2001 рр.. У подальшому, було розроблено та прийнято ще дві програми на 2002-2007 рр. та на 2009-2013 рр.. За означеними програмами хворі на ЦД забезпечувалися безкоштовно препаратами інсуліну та цукрознижуючими ліками.

3. За результатами дослідження вищезазначених цільових програм встановлено, що рівень їх виконання за фінансовими показниками коливався у діапазоні значень від 81,6\% (1999 р.) до 104,1\% за даними 1998 р.. Крім цього нами доведено, що 32004 р. (з 94,3\% до 98,1\%) до 2013 р. спостерігався відносно стабільний характер змін показника рівня (\%) виконання цільових програм по «Цукровому діабету» в Україні.

4. За результатами аналізу Реєстру ЛЗ за асортиментом ліків, що відпускаються хворим на ЦД за програмою «Доступні ліки» встановлено, що зазначений перелік містить 48 асортиментних позицій, серед яких 79,17\% припадає на препарати А10BA02-Метформіну, 14,58\% на препарати А10ВВ09-Гліклазиду, а всього 6,25\% на ліки із групи А10ВВ01-Глібенкламіду. 
5. Встановлено, що співвідношення (\%) між вітчизняними та імпортними ліками у сукупності препаратів А10ВВ01-Глібенкламіду дорівнює 100,0\%:0\% (компанії ПрАТ «Технолог», ТОВ «Фармацевтична компанія «Здоров”я АТ «Фармак»), по групі А10ВВ09 Гліклазиду - 57,14\%:42,86\%, а по препаратах А10ВА02 Метформіну - 78,95\%:21,05\%.

6. За даними аналізу рівня доплати за переліком ліків, що досліджується встановлено, що найбільш доступними, з економічної точки зору для вітчизняних хворих на ЦД II типу є препарати А10ВВ01Глібенкламіду, на другій позиції представлені препарати А10ВВ09 Гліклазиду, а на третій А10BA02 Метформіну. Співвідношення (\%) між кількістю ТН які можуть бути відпущені без доплати та 3 доплатою 3 боку хворого дорівнює $100,0 \%: 0,0 \%$, 57,14\%:42,86\%, 78,95\%:21,05\% відповідно. Доведено, що із асортименту імпортних ліків лише 2 асортименті позиції препаратів можуть бути відпущені без доплати з боку пацієнта.

\section{ЛIТЕРАТУРА}

1. Faulconbridge LF, Wadden TA, Rubin RR, Wing RR, Walkup MP, Fabricatore AN, Coday M, Van Dorsten B, Mount DL, Ewing LJ. One-year changes in symptoms of depression and weight in overweight/obese individuals with type 2 diabetes in the Look AHEAD study. Obesity (Silver Spring). 2012. Vol. 20. P.783-793.

2. National Diabetes Education Program (NDEP) Guiding principles for the care of people with or at risk for diabetes. URL: http://www.niddk.nih.gov (Last accessed: 24.09.2020).

3. Sanz París A, Boj Carceller D, Melchor Lacleta I, Albero Gamboa R. Sugar and diabetes: international recommendations. Nutr Hosp. 2018 Vol. 28 №4. P. 72-80.

4. Standards of Medical Care in Diabetes-2016: Summary of Revisions. Diabetes Care. 2013. Vol. 39. № 1. P.4-5.

5. Inzucchi SE, Bergenstal RM, Buse JB, Diamant M, Ferrannini E, Nauck M, Peters AL, Tsapas A, Wender R, Matthews DR. Management of hyperglycemia in type 2 diabetes, 2015: a patient-centered approach: update to a position statement of the American Diabetes Association and the European Association for the Study of Diabetes. Diabetes Care. 2015. Vol.38. P140-149.

6. Кириченко O.M., Кириченко О.А., Леонченко О.І. Фармакотерапія цукрового діабету 2 типу: оцінка споживання пероральних цукрознижувальних препаратів на українському фармацевтичному ринку. Клінічна фармащія. 2015. №2. С.14-18.

7. Яковлєва Л.В., Кириченко О.М., Лукашевич П.Ю. Оцінка доступності препаратів метформіну та гліклазиду на фармацевтичному ринку України. Ендокринологія.2016, Т.21. № 2. С.119-124.

8. Сучасні підходи до забезпечення цукрознижувальною терапією хворих на цукровий діабет в Україні [Електронний ресурс] / П. Ю. Лукашевич, В. Л. Орленко, М. Д. Тронько. Ендокринологія. 2017. T. 22, № 1. С. 45-50. - Режим доступу: http://nbuv.gov.ua/UJRN/enkrl_2017_22_1_9

9. International Hypoglycaemia Study Group. Minimizing Hypoglycemia in Diabetes. Diabetes Care. 2015. Vol. 38. P. 1583-1591.

10. Lalau JD, Arnouts P, Sharif A, De Broe ME. Metformin and other antidiabetic agents in renal failure patients. Kidney Int. 2015. Vol.87. P. 308-322.

11. Standards of Medical Care in Diabetes-2016: Summary of Revisions. Diabetes Care. 2016. Vol. 39. № 1. P.4-5.

12. National Diabetes Education Program (NDEP) Guiding principles for the care of people with or at risk for diabetes. URL: http://www.niddk.nih.gov (Last accessed: 24.09.2020).

13. Song R. Mechanism of Metformin: A Tale of Two Sites. Diabetes Care. 2016. Vol.39. P.187-189

14. Wing RR, Bolin P, Brancati FL, Bray GA, Clark JM, Coday M, Crow RS, Curtis JM, Egan CM, Espeland MA, et al. Cardiovascular effects of intensive lifestyle intervention in type 2 diabetes. $N$ Engl J Med. 2018. Vol. 369. P. 145-154.

15. Faulconbridge LF, Wadden TA, Rubin RR, Wing RR, Walkup MP, Fabricatore AN, Coday M, Van Dorsten B, Mount DL, Ewing LJ. One-year changes in symptoms of depression and weight in overweight/obese individuals with type 2 diabetes in the Look AHEAD study. Obesity (Silver Spring). 2016.Vol. 20. P.783-793.

16. Shin NR, Lee JC, Lee HY, Kim MS, Whon TW, Lee MS, Bae JW. An increase in the Akkermansia spp. population induced by metformin treatment improves glucose homeostasis in diet-induced obese mice. Gut. 2015. Vol.63. P.727-735.

17. Кірсанов Д. Програма «Доступні ліки»: хід реалізації під патронатом НСЗУ. Щотижневик «Аптека». 2020. №34 (1255). URL: https://www.apteka.ua/article/562294 (дата звернення: 06.11.2020).

18. Кірсанов Денис. Програма «Доступні ліки»: про що говорять цифри. Щотижневик «Аптека». URL: https://www.apteka.ua/article/462948 (дата звернення: 16.06.2020).

19. Оцінка програми «Доступні ліки» Звіт ВООЗ, 2018 р., Publications WHO Regional Office for Europe. 60 c.

20. ВООЗ представила результати оцінки програми «Доступні ліки». Надано рекомендації Щотиждневик «Аптека». 2018. № 41 (1162). URL: https://www.apteka.ua/article/476315 (дата звернення: 29.11.2020).

21. Наказ MO3 України від 11.08.2020 №1851 Щотижневик «Аптека». URL: https://www.apteka.ua/article/559244 (дата звернення: 25.11.2020). 